\title{
Editorial: Roles and mechanisms of parasitism in aquatic microbial communities
}

\author{
Télesphore Sime-Ngando ${ }^{1,2 *}$, Kevin D. Lafferty ${ }^{3}$ and David G. Biron ${ }^{1,2}$ \\ 1 Université Clermont Auvergne, Université Blaise Pascal, Clermont-Ferrand, France, ${ }^{2}$ Laboratoire Microorganismes: Génome \\ et Environnement, Centre National de la Recherche Scientifique, Aubière, France, ${ }^{3}$ Western Ecological Research Center -The \\ United States Geological Survey, Marine Science Institute, University of California, Santa Barbara, Santa Barbara, CA, USA
}

Keywords: parasitism, hyperparasitism, ecology, food web dynamics, microbial communities

Our research topic on the roles and mechanisms of parasitism in aquatic microbial communities should be of broad interest, given that there are probably more parasitic species than freeliving ones (Windsor, 1998), a hypothesis increasingly supported by next generation sequencing technologies of microbial taxa (Sime-Ngando and Niquil, 2011). We know little about the parasites of microbes, but recent research suggests that they affect food-web dynamics, biogeochemical cycling, the functioning of ecosystems and related services, and host evolution. Furthermore, several new research topics, such as interactomics, molecular dialogue, host manipulation by parasites (Cézilly et al., 2014; Biron et al., 2015), "beneficial" parasites (Roossinck, 2011;

OPEN ACCESS

Edited by: Jonathan P. Zehr University of California, Santa Cruz, USA

Reviewed by: Spencer V. Nyholm University of Connecticut, USA

*Correspondence: Télesphore Sime-Ngando, telesphore.sime-ngando@ univ-bpclermont.fr

Specialty section:

This article was submitted to Aquatic Microbiology, a section of the journal Frontiers in Microbiology

Received: 02 March 2015 Accepted: 24 April 2015 Published: 12 May 2015

Citation:

Sime-Ngando T, Lafferty KD and Biron DG (2015) Editorial: Roles and mechanisms of parasitism in aquatic microbial communities. Front. Microbiol. 6:446. doi: 10.3389/fmicb.2015.00446 Parfrey et al., 2014), priming of the host immune system (Llewellyn et al., 2014), microbiomics (Llewellyn et al., 2014), and tripartite symbiosis (Rohwer and Thurber, 2009; Gleason et al., 2014), are filled with interesting questions. We ordered the thirteen papers in this issue according to the biological complexity of parasites, from phages-bacteria, phage-bacteriaanimal, microparasite-microbe, microparasite-microhyperparasite-microbe, microparasite-animal to macroparasite-microbe interactions.

New findings in the papers include the conceptualization of viral lifestyles and the extension of their role as microbe killers, cell partners, or metabolic manipulators (Sime-Ngando, 2014). These relationships have applications for economics and conservation. For instance, shore-based abalone aquaculture can discharge pathogens like the intracellular bacterium Candidatus Xenohaliotis californiensis (WS-RLO), with potential impacts to wild abalone (Lafferty and Ben-Horin, 2014). However, a novel bacteriophage now infects the WS-RLO, improving the survival of infected abalone and thereby offering a potential tool for population management via phage therapy (Friedman et al., 2014). The importance of such tripartite interactions relates to Gleason et al. (2014) argument that parasites of parasites may increase the complexity of food webs, and play significant roles in suppressing diseases of animals, plants, or algae. The ecological importance of such disease dynamics is illustrated well by new quantitative data and modeling that shows how during blooms of inedible algae in freshwater lakes, (i) chytrid parasites of phytoplankton are able to shape aquatic ecosystems by altering sinking fluxes or determining system stability (Kagami et al., 2014), and (ii) divert about 20\% of primary production to edible zoospores that comprise $50-57 \%$ of the zooplankton diet (Rasconi et al., 2014). This work is remarkable given how challenging it is to diagnose parasites of microbes in natural systems (Karpov et al., 2014). Economic incentive for improved diagnosis stems from the effects of infection dynamics on commercial-scale algal monocultures for bioenergy and chemical production (Carney and Lane, 2014). Several topics in this collection deal with microbial parasites and the microbiome of fishes and animals, demonstrating, for example, that viral, prokaryotic and small-eukaryotic parasites affect conservation and food security (Gozlan et al., 2014). For instance, indigenous 
microbiota affects innate and adaptive immunity, fish digestion, and nutrient metabolism (Llewellyn et al., 2014). The extent to which aquatic microbes differ from other small eukaryote communities is highlighted by Parfrey et al. (2014) who use high-throughput sequencing to consider how microbes in the mammalian gut reflect both host phylogeny and diet, and are distinctive from those in aquatic and terrestrial habitats. The microbiome might even influence host behavior as a result of the molecular crosstalk between a manipulative parasite and its host, disturbing the synthesis of neuroactive molecules (Biron et al., 2015). We end with Cézilly et al. (2014), who consider the hypothesis of conflict vs. cooperation in host manipulation, and provide empirical evidence that microorganisms can have synergistic and antagonistic interactions with co-occurring parasites.

We hope the contributions to this collection bring a new focus to the aquatic sciences. Microbial interactions are clearly important and largely unknown. There are still methodological barriers to assessing prokaryotic and eukaryotic parasites of aquatic microbes (Sime-Ngando and Niquil, 2011),

\section{References}

Biron, D. G., Bonhomme, L., Coulon, M., and Øverli, Ø. (2015). Microbiomes,plausible players or not in alteration of host behavior. Front. Microbiol. 5:775. doi: 10.3389/fmicb.2014.00775

Carney, L. T., and Lane, T. W. (2014). Parasites in algae mass culture. Front. Microbiol. 5:278. doi: 10.3389/fmicb.2014.00278

Cézilly, F., Perrot-Minnot, M.-J., and Rigaud, T. (2014). Cooperation and conflict in host manipulation: interactions among macro-parasites and micro-organisms. Front. Microbiol. 5:248. doi: 10.3389/fmicb.2014. 00248

Friedman, C. S., Wight, N., Crosson, L. M., VanBlaricom, G. R., and Lafferty, K. D. (2014). Reduced disease in black abalone following mass mortality: phage therapy and natural selection. Front. Microbiol. 5:78. doi: $10.3389 /$ fmicb.2014.00078

Gleason, F. H., Lilje, O., Marano, A. V., Sime-Ngando, T., Sullivan, B. K., Kirchmair, M., et al. (2014). Ecological functions of zoosporic hyperparasites. Front. Microbiol. 5:244. doi: 10.3389/fmicb.2014.00244

Gozlan, R. E., Marshall, W., Lilje, O., Jessop, C., Gleason, F. H., and Andreou, D. (2014). Current ecological understanding of fungal-like pathogens of fish: what lies beneath? Front. Microbiol. 5:62. doi: 10.3389/fmicb.2014. 00062

Kagami, M., Miki, T., and Takimoto, G. (2014). Mycoloop: chytrids in aquatic food webs. Front. Microbiol. 5:166. doi: 10.3389/fmicb.2014.00166

Karpov, S., Mamkaeva, M. A., Aleoshin, V., Nassonova, E., Lilje, O., and Gleason, F. H. (2014). Morphology, phylogeny, and ecology of the aphelids (Aphelidea, Opisthokonta) and proposal for the new superphylum Opisthosporidia. Front. Microbiol. 5:112. doi: 10.3389/fmicb.2014.00112

Lafferty, K., and Ben-Horin, T. (2014). Abalone farm discharges the withering syndrome pathogen into the wild. Front. Microbiol. 4:373. doi: 10.3389/fmicb.2013.00373

Llewellyn, M., Boutin, S., Hoseinifar, S. H., and Derome, N. (2014). Teleost microbiomes: the state of the art in their characterization, manipulation although recent advancements provide new opportunities (Marano et al., 2012), which we expect will lead to, a predictive understanding of the role of parasitism in aquatic systems in particular, and of aquatic ecosystem functioning in general.

\section{Acknowledgments}

We thank all the contributing authors and coauthors to the Research Topic, some of which also have reviewed submissions from colleagues. We are particularly indebted to the editorial team of Frontiers in Microbiology and to reviewers who worked hard for many months and provided invaluable comments: AC Baudoux, GW Beakes, S Bosshart, F Delbac, S Dryhurst, AM Dunn, H El Alaoui, ME Grigg, PR Girguis, LT Guerra, B Ibelings, M Kagami, JF Mangot, JD Moore, S Morand, H Moreau, S Neuhauser, RJ Newton, N Niquil, Ø Øyvind, P Poirier, J Romero, A Sukenik, KW Tang, MA Tiirola, and JP Zehr. This ebook was supported by the French ANR project ROME (ANR 12 BSV7 0019 01). and importance in aquaculture and fisheries. Front. Microbiol. 5:207. doi: 10.3389/fmicb.2014.00207

Marano, A. V., Edwards, J. E., Gleason, F. H., Bärlocher, F., Pires-Zottarelli, C. L. A., Lilje, O., et al. (2012). Quantitative methods for the analysis of zoosporic fungi. J. Microb. Methods 89, 22-32. doi: 10.1016/j.mimet.2012.02.003

Parfrey, L. W., Walters, W. A., Lauber, C. L., Clemente, J. C., Berg-Lyons, D., Brunelle, J. M., et al. (2014). Communities of microbial eukaryotes in the mammalian gut within the context of environmental eukaryotic diversity. Front. Microbiol. 5:298. doi: 10.3389/fmicb.2014.00298

Rasconi, S., Grami, B., Niquil, N., Jobard, M., and Sime-Ngando, T. (2014). Parasitic chytrids sustain zooplankton growth during inedible algal bloom. Front. Microbiol. 5:229. doi: 10.3389/fmicb.2014.00229

Rohwer, F., and Thurber, R. V. (2009). Viruses manipulate the marine environment. Nature 459, 207-212. doi: 10.1038/nature08060

Roossinck, M. J. (2011). The good viruses: viral mutualistic symbioses. Nat. Rev. Microbiol. 9, 99-108. doi: 10.1038/nrmicro2491

Sime-Ngando, T. (2014). Environmental bacteriophages: viruses of microbes in aquatic ecosystems. Front. Microbiol. 5:355. doi: 10.3389/fmicb.2014.00355

Sime-Ngando, T., and Niquil, N. (eds.). (2011). Disregarded Microbial Diversity and Ecological Potentials in Aquatic Systems. New York, NY: Springer.

Windsor, D. A. (1998). Most of the species on earth are parasites. Int. J. Parsitol. 28, 1939-1941. doi: 10.1016/S0020-7519(98)00153-2

Conflict of Interest Statement: The authors declare that the research was conducted in the absence of any commercial or financial relationships that could be construed as a potential conflict of interest.

Copyright (c) 2015 Sime-Ngando, Lafferty and Biron. This is an open-access article distributed under the terms of the Creative Commons Attribution License (CC BY). The use, distribution or reproduction in other forums is permitted, provided the original author(s) or licensor are credited and that the original publication in this journal is cited, in accordance with accepted academic practice. No use, distribution or reproduction is permitted which does not comply with these terms. 